\title{
Opiate Withdrawal Induces Narp in the Extended Amygdala
}

\author{
Irving M Reti*,' and Jay M Baraban ${ }^{1,2}$ \\ 'Department of Psychiatry and Behavioral Sciences, The Johns Hopkins University School of Medicine, Baltimore, MD, USA; ${ }^{2}$ Department of \\ Neuroscience, The Johns Hopkins University School of Medicine, Baltimore, MD, USA
}

\begin{abstract}
The negative affective states associated with drug withdrawal produce long-lasting behavioral effects thought to play a central role in the development and maintenance of dependence. However, little is known about the molecular mechanisms mediating the long-term effects of drug withdrawal. Neuronal activity-regulated pentraxin (Narp) is a secreted neuronal immediate early gene (IEG) product that regulates AMPA receptor clustering at synapses. As both IEGs and changes in AMPA receptor trafficking mediate enduring forms of neuronal plasticity, we have assessed whether Narp could be involved in the molecular adaptations accompanying drug withdrawal. To this end, we checked the effect of opiate withdrawal on Narp expression in the extended amygdala, a brain region closely linked to the aversive effects of drug withdrawal. We found a marked increase in the number of Narp-positive cells in this region following opiate withdrawal triggered by either low doses of opiate antagonists or by 'natural withdrawal', removal of the morphine pellets used to induce dependence. In contrast, Arc, another 'effector' IEG, was not induced by opiate withdrawal. As expected, pretreatment of animals with clonidine, which blocks opiate withdrawal, suppresses Narp induction in this paradigm. These results implicate Narp in mediating the long-term, aversive behavioral effects induced by opiate withdrawal.

Neuropsychopharmacology (2003) 28, 1606-16/3, advance online publication, I4 May 2003; doi: I 0.1038/sj.npp. I 300205
\end{abstract}

Keywords: opiate withdrawal; immediate early gene; AMPA receptor; amygdala; synaptic plasticity; neuronal pentraxin; BNST

\section{INTRODUCTION}

A major focus of drug abuse research is to define the molecular adaptations triggered by drug administration, which induce and sustain substance abuse and dependence. As the long-lasting behavioral alterations induced by drugs of abuse can be viewed as a form of memory, there has been considerable interest in the proposal that similar molecular mechanisms may be involved in generating enduring forms of synaptic plasticity and long-lasting effects of drugs of abuse (Hyman and Malenka, 2001; Nestler, 2001). This line of reasoning has spawned interest in examining the role of neuronal immediate early genes (IEGs) in drug-induced plasticity. As these genes are rapidly induced by neuronal stimulation, they represent a mechanism by which drug administration could elicit long-term adaptations in neuronal function that underlie their reinforcing properties. For example, chronic psychostimulant administration leads to a shift in the pattern of expression of Fos family members in the nucleus accumbens (NAc) with the accumulation of Delta FosB after repeated treatments (Hope et al, 1994) and

\footnotetext{
*Correspondence: Dr I Reti, The Johns Hopkins Hospital, Department of Psychiatry, $600 \mathrm{~N}$. Wolfe Street, Meyer 3-181, Baltimore, MD 21205, USA, Tel: + I 410955 2500, Fax: + I 410 614 6249,

E-mail: imreti@jhmi.edu

Received 03 December 2002; revised 07 March 2003; accepted I। March 2003

Online publication: 26 March 2003 at http://www.acnp.org/citations/ Npp032603444/default.pdf
}

manipulation of Delta FosB levels changes sensitivity to cocaine (Kelz et al, 1999; Nestler et al, 2001).

Although much attention has been paid to delineating the neural pathways underlying the rewarding properties of drugs of abuse, it has been proposed that the negative affective states associated with drug withdrawal also play an important role in motivating continued compulsive drug use (Gawin and Kleber, 1986; Koob, 1999). Studies aimed at mapping the circuits mediating the aversive responses to drug withdrawal have focused attention on a set of structures referred to as the 'extended amygdala', which includes the central nucleus of the amygdala (CeA), the bed nucleus of the stria terminalis (BNST), and the shell of the NAc (Koob, 1999; Delfs et al, 2000). As the aversive effects of drug withdrawal can be extremely long lasting, it is conceivable that its enduring effects may be mediated by induction of IEGs. Support for this line of reasoning has come from recent studies demonstrating that opiate withdrawal is associated with heightened activation of CREBand CRE-mediated transcription in the CeA as well as other parts of the extended amygdala (Shaw-Lutchman et al, 2002). Moreover, c-Fos expression in the extended amygdala induced by opiate withdrawal parallels the development of conditioned place aversion, a sensitive measure of the dysphoric effects of drug withdrawal (Gracy et al, 2001).

In recent studies neuronal activity-regulated pentraxin (Narp) has been identified as a neuronal IEG that is induced in hippocampal and cortical neurons by stimuli that produce enduring forms of synaptic plasticity (Tsui et al, 
1996). Initial characterization of Narp protein confirmed that, like other pentraxin family members, it is secreted. Consistent with this finding, anatomical studies have revealed that it is preferentially targeted to axonal projections and terminals (O'Brien et al, 1999; Reti et al, 2002a). Studies examining the effect of Narp overexpression demonstrated that it elicits an increase in the number of excitatory, but not inhibitory, synapses in primary neuronal cultures. In addition, Narp self-multimerizes to form large surface clusters that co-aggregate with AMPA receptors. Taken together, these findings indicate that Narp, secreted from presynaptic terminals, may help modulate synapse formation or efficacy by regulating AMPA receptor clustering at synapses (O'Brien et al, 1999, 2002).

To test whether Narp could be involved in the molecular adaptations accompanying the aversive state induced by drug withdrawal, we checked the effect of opiate withdrawal on Narp expression in the extended amygdala. We found a marked increase in Narp expression in the CeA, BNST and shell of the NAc following opiate withdrawal triggered either by low-dose opiate antagonists or by removal of the morphine pellets used to induce dependence. In contrast, Arc, another 'effector' IEG (Lyford et al, 1995), was not induced in this paradigm. Moreover, pretreatment of animals with clonidine, which blocks opiate withdrawal, suppressed Narp expression in this paradigm. These findings implicate Narp in the synaptic plasticity processes underlying long-lasting aversive effects of opiate withdrawal.

\section{RESULTS}

Narp Immunoreactivity in the Central Nucleus of the Amygdala is Induced by Opiate Withdrawal Precipitated by Low Doses of Opiate Antagonists

In initial studies, we examined Narp immunostaining in the CeA of naïve animals and found very few Narp-positive cells in this area $(<5 /$ side; Figure $1 \mathrm{a})$. To check the effect of opiate withdrawal on Narp expression in this area, opiatedependent rats were killed $4 \mathrm{~h}$ after receiving naltrexone $(100 \mu \mathrm{g} / \mathrm{kg}$, s.c.). This treatment produced a marked increase in the average number of Narp-positive cells in the CeA (78 cells/side; Figures 1b-e and 2) that were located predominantly in the lateral portion of the nucleus. To check that Narp expression is induced by opiate withdrawal, and not by the preceding exposure to opiates, we confirmed that normal saline administered to opiate-dependent rats does not elicit an increase in Narp-positive cells in the CeA (5 cells/side; Figure 2). Furthermore, Narp expression was unaffected by naltrexone $100 \mu \mathrm{g} / \mathrm{kg}$ given to opiate naïve animals ( 7 cells/side; Figure 1f). We also noted an increase in Narp fiber staining in the CeA. As cells in the lateral portion of the CeA project to the dorsomedial portion of the CeA (Cassell et al, 1999), we assessed the density of Narppositive fiber staining by superimposing a $5 \times 5$ grid of $50 \mu \mathrm{m}$ squares over this region and counting the number of squares that contained Narp fibers. Narp fiber staining in this region from animals killed $4 \mathrm{~h}$ after opiate withdrawal received a score of $15 \pm 1.8$ (out of a maximal score of 25) on this measure. In contrast, the scores for Narp fibers in this region were significantly lower in opiate naïve animals
$(4 \pm 0.6$ squares; $p<0.01)$ and in animals given naltrexone $100 \mu \mathrm{g} / \mathrm{kg}$ only $(5 \pm 1.3$ squares; $p<0.01)$.

Since long-term effects of opiate withdrawal can be induced by lower doses of naltrexone than that used above (Mucha, 1987), we examined the effects of lower doses of naltrexone on Narp expression in the CeA (Figure 2). We found that naltrexone $10 \mu \mathrm{g} / \mathrm{kg}$ given to opiate-dependent animals also increases the number of Narp-positive cells. Naltrexone $1 \mu \mathrm{g} / \mathrm{kg}$ produced a smaller increase that did not reach significance. As naloxone is widely used to precipitate opiate withdrawal, we also checked its effect on Narp induction. Although it also elicits Narp induction, naloxone produced a weaker response when given at the same dose as naltrexone (Figure 2). This finding fits with in vitro studies demonstrating that naloxone has lower affinity than naltrexone for the opiate receptor (Pert et al, 1973; Blasig et $a l, 1976)$. In addition, it may also reflect the longer duration of naltrexone's actions in vivo (Berkowitz et al, 1975; Wall et al, 1981).

Narp Immunoreactivity in the Bed Nucleus of the Stria Terminalis and the Shell of the NAc is Induced by Opiate Withdrawal Precipitated by Low Doses of Opiate Antagonists

We observed the same pattern of Narp induction in the BNST and shell of the NAc (Figure 3a-f). Opiate withdrawal precipitated by naltrexone $100 \mu \mathrm{g} / \mathrm{kg}$ induced significant increases in cell body staining in both these regions (Figure 3g), but withdrawal precipitated by naltrexone $10 \mu \mathrm{g} / \mathrm{kg}$ did not result in significant changes in Narp staining.

\section{Narp is also Induced in the Extended Amygdala with 'Natural Withdrawal'}

As opiate antagonist-mediated opiate withdrawal is different from the clinical syndrome, we also examined Narp expression following 'natural withdrawal', that is, morphine pellet removal, which more closely matches the human drug withdrawal scenario. This procedure yielded a similar Narp response to that induced by opiate antagonists (Figure 4). Somatic signs noted in these animals were tremor, irritability, ptosis, and diarrhea. In animals killed $8 \mathrm{~h}$ after pellet removal, the number of Narp-positive cells in the CeA, BNST, and shell of the NAc increased by approximately four-fold compared with that of opiate-dependent animals subjected to surgical manipulation only.

\section{Specificity of Narp Induction in the CeA with Opiate Withdrawal}

As several IEGs have previously been implicated in playing a role in drug-induced plasticity paradigms, we compared the effect of opiate withdrawal on Narp induction with other IEGs in the CeA (Figure 5). We chose to examine c-Fos, as others have noted it to be induced with opiate withdrawal (Gracy et al, 2001). Unlike Narp, which displays a relatively slow time course compared with other IEGs (Berke et al, 1998), c-Fos induction is rapid and transient. Accordingly for these studies, animals were killed at $1 \mathrm{~h}$ after naltrexone administration. Both Narp and c-Fos immunoreactive cells 

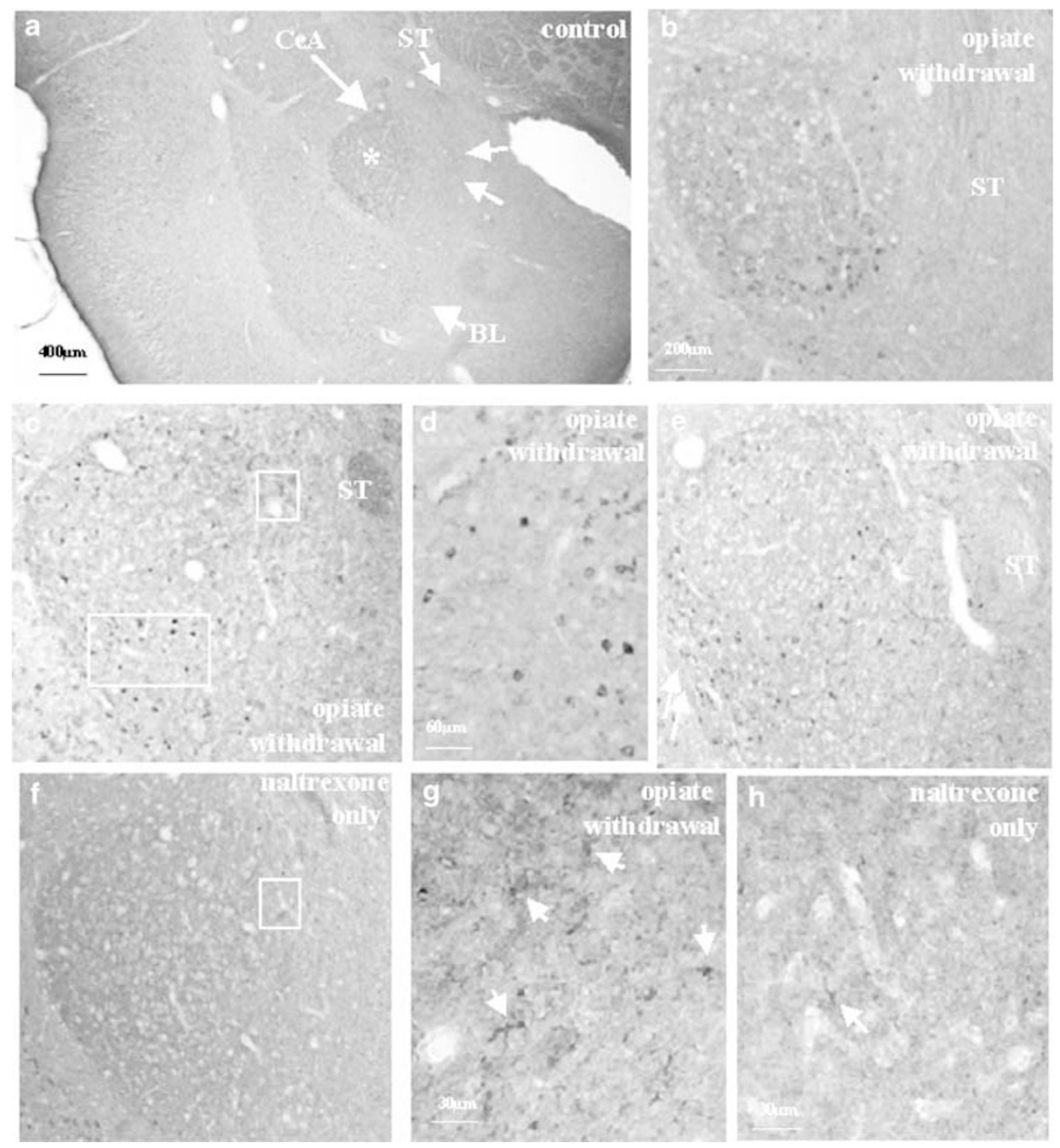

Figure I Narp immunoreactivity in the central nucleus of the amygdala is induced by opiate withdrawal triggered by naltrexone in opiate-dependent animals. Panel (a) demonstrates a low-power view of Narp immunostaining in the amygdala of an untreated animal. The symbol $(*)$ indicates the lateral portion of the CeA and the arrows indicate the medial extent of the CeA. At $4 \mathrm{~h}$ after opiate withdrawal triggered by naltrexone $100 \mu \mathrm{g} / \mathrm{kg}$, robust Narp staining is induced in the CeA (panels (b-e)), whereas it is minimal in animals treated with naltrexone $100 \mu g / k g$ that have been implanted with placebo pellets (panel (f)); Narp staining is constitutively present in the basolateral nucleus (BL). Panels (b-e) demonstrate Narp staining in the posterior (b), middle (c) and anterior (e) CeA that correspond to levels AP 5.0, 5.4 and 5.8 (Cassell et al, 1986), respectively. The variable position of the stria terminalis (ST) is a reliable landmark indicating the level. Narp cell body staining is mainly restricted to the lateral portion of the CeA, although scattered cell bodies were occasionally seen in the medial portion of the nucleus also. Anteriorly, Narp cell body staining is particularly prominent in the lateral capsular region (panel (e)). Panel (d) is a higher power view of panel (c; rotated at $90^{\circ}$ ) demonstrating large fusiform Narp-positive cells, about $25 \mu \mathrm{m}$ in diameter. Panels ( $\mathrm{g}$ and $\mathrm{h}$ ) demonstrate high-power views of Narp fiber staining in the dorsomedial portions of panels ( $c$ and $f$ ), indicated by small white boxes, and illustrate higher density fiber staining in an opiate-withdrawn rat (g) than a rat subjected to naltrexone $100 \mu \mathrm{g} / \mathrm{kg}$ only.

are found predominantly in the lateral portion of the CeA; however, there appeared to be more c-Fos-positive cells. Whereas opiate withdrawal triggered by naltrexone $100 \mu \mathrm{g} /$ $\mathrm{kg}$ resulted in approximately 80 Narp-positive cells on average in the CeA assessed at $4 \mathrm{~h}$ after onset of withdrawal (Figure 5a), the number of Fos-immunoreactive cells was typically over 150 (Figure $5 \mathrm{~b}$ ) at the $1 \mathrm{~h}$ time point. We also checked the effect of opiate withdrawal on the expression of Arc, an 'effector' IEG. However, in contrast to Narp, we were unable to detect Arc induction (Figure 5c). As a positive control for the Arc immunostaining procedure, we confirmed the presence of readily detectable Arc-immunoreactive cells in the hippocampus from the same animal (data not shown) and from an animal that had received an electroconvulsive seizure (Figure $5 \mathrm{~d}$ ).

\section{Blockade of Narp Expression by PreTreatment with Clonidine}

Previous studies have demonstrated that clonidine, an alpha2-antagonist, blocks both somatic signs and aversive conditioning induced by opiate withdrawal (Kosten, 1994; Nader and van der Kooy, 1996). Thus, if Narp is involved in mediating long-term aspects of aversive conditioning, then clonidine should block Narp induction triggered by opiate withdrawal. To test this prediction, we examined the effect of pretreating opiate-dependent rats with clonidine $(50 \mu \mathrm{g} /$ $\mathrm{kg}$, i.p.) prior to administering naltrexone $(100 \mu \mathrm{g} / \mathrm{kg}$, s.c.). As expected, these animals displayed few somatic signs of opiate withdrawal during the four-hour interval prior to being killed. Furthermore, we found that clonidine sup- 


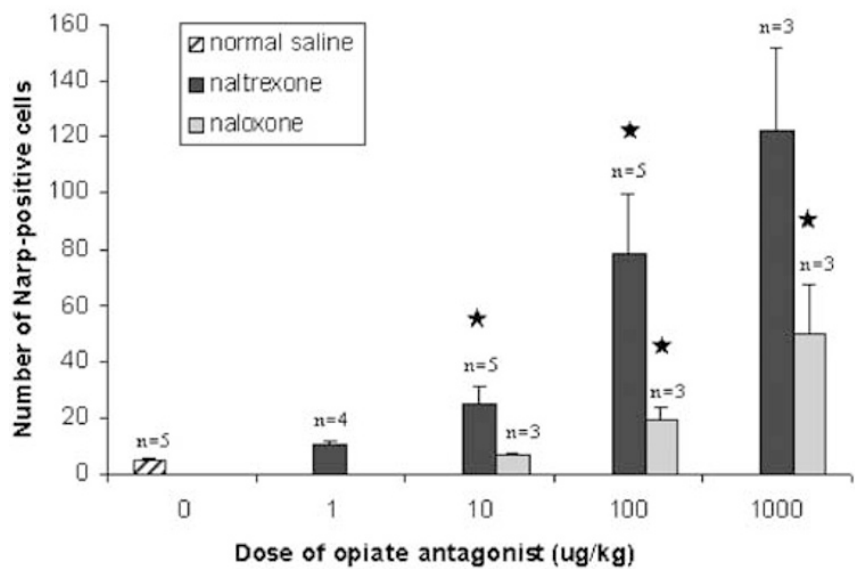

Figure 2 Narp immunoreactivity in the central nucleus of the amygdala is induced by low-dose opiate antagonists. Bar graph showing the mean number of Narp-immunoreactive cells $( \pm$ SEM) per side produced in the central nucleus of the amygdala (CeA). ANOVA showed a main effect of dose for naltrexone: $F(4,17)=1 \mid(p<0.0005)$. Post hoc analysis (Student's $t$-test with Bonferroni correction) indicated that doses of naltrexone 10 , 100 , and $1000 \mu \mathrm{g} / \mathrm{kg}$ differed significantly from control $(* p<0.05)$. Naltrexone I $\mu \mathrm{g} / \mathrm{kg}$ did not reach significance after correcting for multiple comparisons. ANOVA showed a main effect of dose for naloxone also: $F(3, I 0)=7(p<0.01)$. Post hoc analysis indicated that doses of naloxone 100 and $1000 \mu \mathrm{g} / \mathrm{kg}$ differed significantly from control $(* p<0.05)$.

pressed Narp expression in the CeA by $85 \%$ compared with control opiate-dependent rats that received naltrexone without clonidine pretreatment. (Figure $6 ; p<0.05$ ). We also found that with clonidine pretreatment, Narp cell body staining was also suppressed in the BNST and shell of the NAc. In the BNST, it was suppressed by $66 \%$, falling from an average of $32 \pm 3$ cells in opiate-withdrawn animals to $11 \pm 1.9$ cells in animals pretreated with clonidine $(p<0.01)$. In the shell, Narp immunostaining was suppressed by $65 \%$, falling from an average of $23 \pm 1.2$ cells in opiate-withdrawn animals to $8 \pm 1.9$ cells in animals pretreated with clonidine $(p<0.01)$.

\section{DISCUSSION}

The major finding of this study is that Narp is induced in several parts of the extended amygdala by opiate withdrawal. As these structures play a key role in mediating aversive responses to a wide variety of stimuli, including opiate withdrawal, Narp may mediate synaptic modifications that underlie the long-lasting aversive consequences of opiate withdrawal. Pharmacological characterization of Narp induction by opiate withdrawal supports this view. By varying the dose of opiate antagonist used to elicit opiate withdrawal, we found that Narp induction in the CeA is triggered by low doses that closely parallel the development of conditioned place aversion (Mucha, 1987; Gracy et al, 2001). Furthermore, clonidine, which blocks conditioned place aversion elicited by opiate withdrawal, also suppresses Narp induction in the extended amygdala. Recent studies indicate that IEGs play a critical role in mediating long-term aspects of synaptic plasticity in other behavioral paradigms (Guzowski and McGaugh, 1997; Guzowski et al, 2000; Jones et al, 2001). Thus, these findings suggest that Narp, and

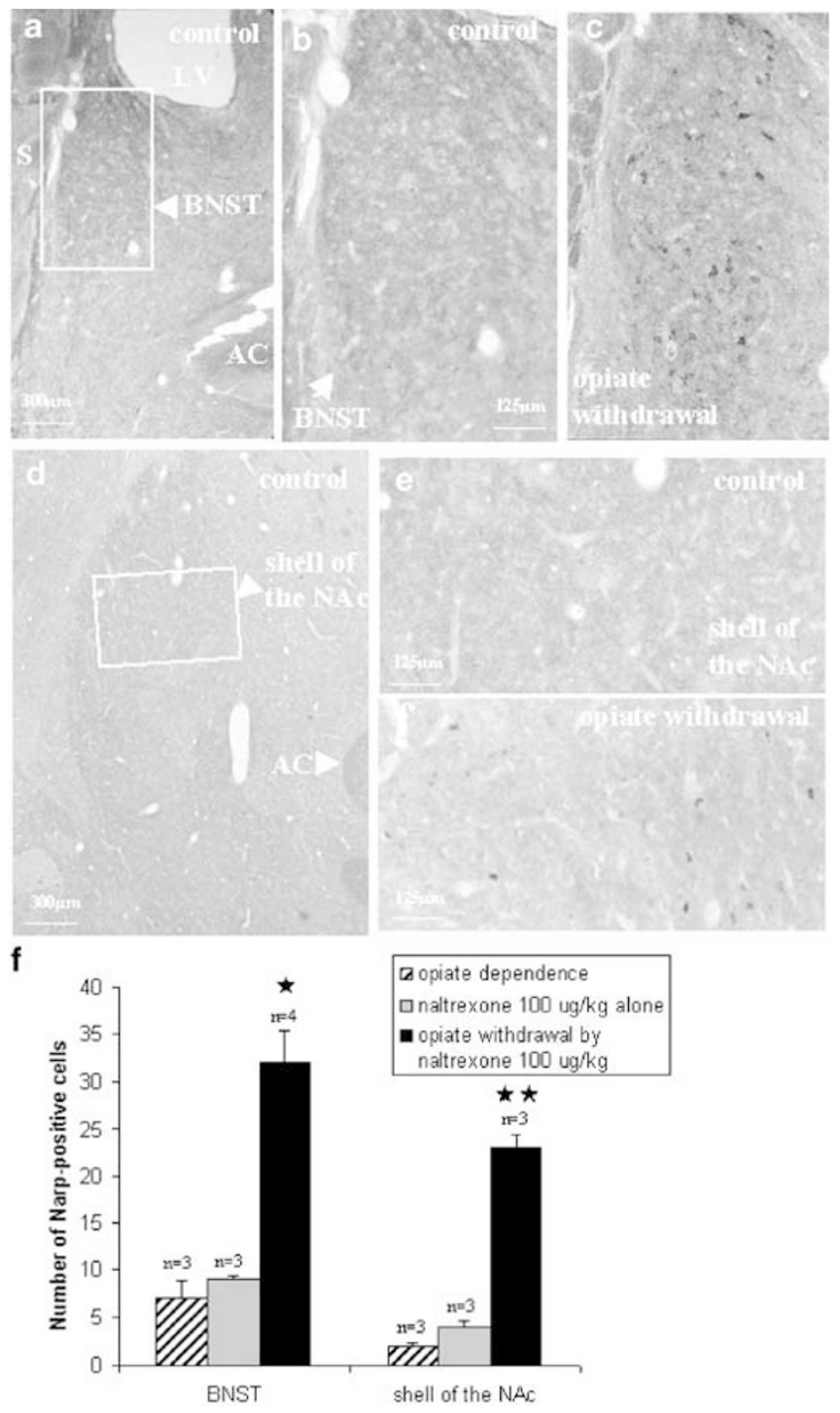

Figure 3 Narp immunoreactivity in the BNST and shell of the NAc is induced by opiate withdrawal triggered by naltrexone in opiate-dependent animals. Panels (a) and (b) demonstrate low- and high-power views of the BNST in a control animal. At $4 \mathrm{~h}$ after opiate withdrawal triggered by naltrexone $100 \mu g / \mathrm{kg}$, robust Narp staining is present in the BNST (panel (c)). The pattern of Narp staining appears to correspond to the lateral portion of the BNST as depicted in Figure 15 of Paxinos and Watson (1986). Panels (d) and (e) demonstrate low- and high-power views of the shell of the NAc in a control animal. At $4 \mathrm{~h}$ after opiate withdrawal triggered by naltrexone $100 \mu \mathrm{g} / \mathrm{kg}$, scattered Narp cell body staining is present in the shell (panel (e)). The increases in cell body staining following opiate withdrawal were significant in both these regions (panel (f); $* 0<0.05$; ** $p<0.01$ ). Since the extent of the shell is greater than the boxed area (panels (d) and (e)), the number of cells shown in the boxed area is only a fraction of the number shown in the graph. We also observed a significant increase in Narp cell body staining in the lateral septum after opiate withdrawal triggered by naltrexone $100 \mu \mathrm{g} / \mathrm{kg}$. Opiate-withdrawn animals averaged $21 \pm 3$ cells compared with $6 \pm 2$ cells in opiatedependent animals and $5 \pm 0.5$ cells in animals treated with naltrexone $100 \mu \mathrm{g} / \mathrm{kg}$ only. AC - anterior commissure; LV-lateral ventricle; S-striatum.

presumably other IEGs, serve a similar role in mediating long-term changes in amygdala pathways following opiate withdrawal and possibly other aversive stimuli, as well. 


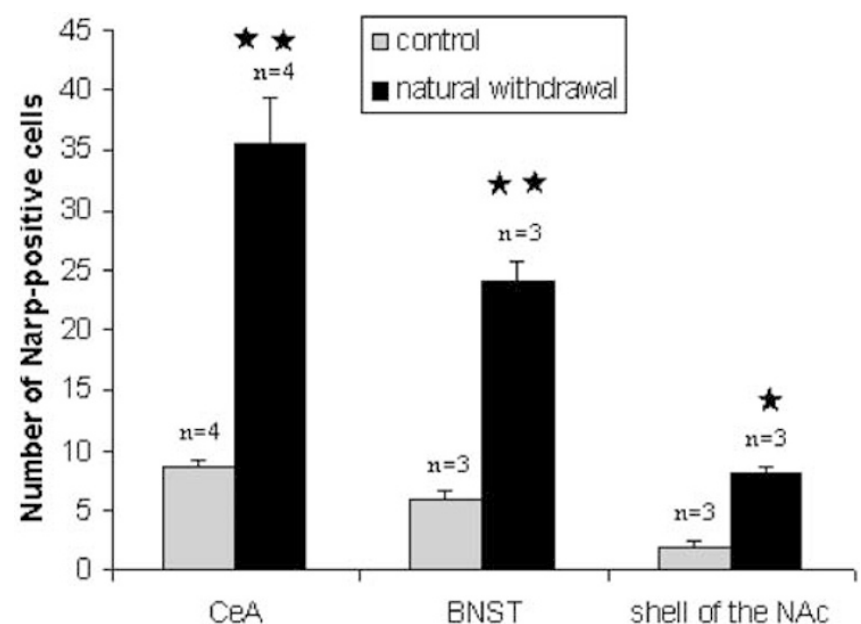

Figure 4 Narp is also induced in the extended amygdala with 'natural withdrawal'. Bar graph showing the mean number of Narp-immunoreactive cells ( \pm SEM) per side produced in the CeA, BNST, and shell of the NAc. Student's t-test indicates that animals experiencing opiate withdrawal triggered by morphine pellet removal have significantly higher levels of Narp-positive cells in each of these regions $8 \mathrm{~h}$ after surgery than control animals treated with sham surgery $\left(* p<0.005\right.$; ${ }^{*} * p<0.00$ I).

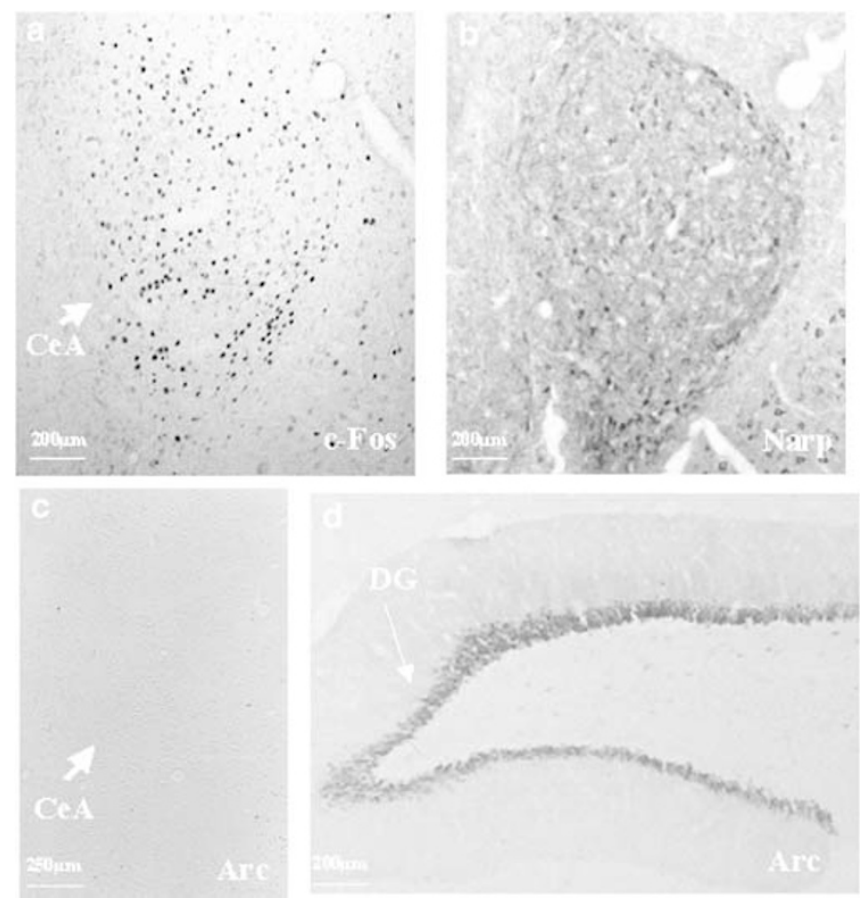

Figure 5 Specificity of Narp induction in the central nucleus of the amygdala (CeA) with opiate withdrawal. Panel (a) demonstrates Narp immunoreactivity in the CeA after opiate withdrawal triggered by naltrexone $100 \mu \mathrm{g} / \mathrm{kg}$. The same dose of naltrexone typically induces many more Fos-immunoreactive cells (panel (b)), whereas another 'effector' IEG, Arc, is not induced with opiate withdrawal (panel (c)). Plate (d) shows robust Arc-immunoreactivity in the dentate granule cells (arrow) of an animal administered electroconvulsive seizure $4 \mathrm{~h}$ earlier indicating that the absence of Arc staining in the CeA was not related to a technical problem with the immunostaining. DG-dentate gyrus.

The potential involvement of other IEGs in this plasticity paradigm prompted us to check whether Arc, an IEG required for induction of the late phase of hippocampal LTP

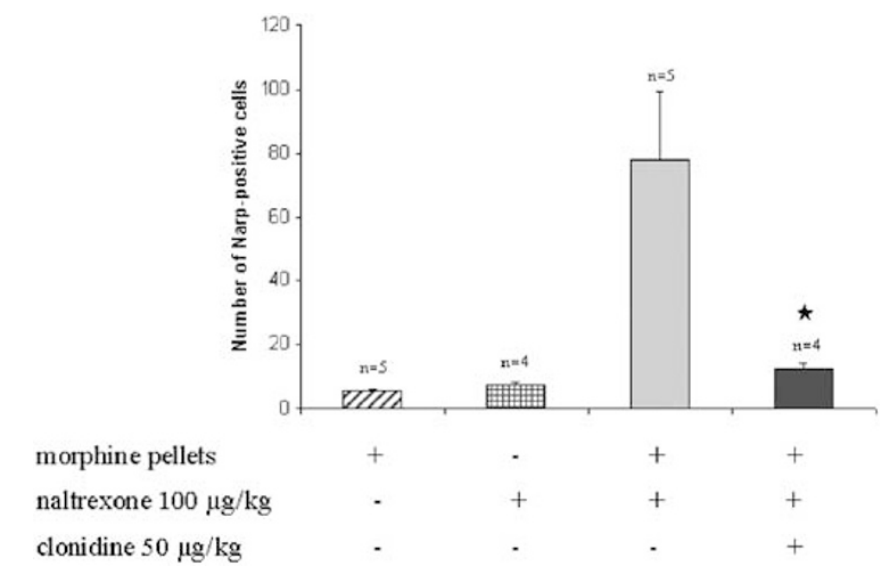

Figure 6 Blockade of Narp expression by pretreatment with clonidine. Bar graph showing the mean number of Narp-immunoreactive cells ( \pm SEM) per side produced in the CeA. Student's t-test reveals that Narp expression in the $\mathrm{CeA}$ is significantly diminished in opiate-dependent animals receiving clonidine $50 \mu \mathrm{g} / \mathrm{kg}$, i.p. $20 \mathrm{~min}$ prior to naltrexone $100 \mu \mathrm{g} /$ $\mathrm{kg}$, compared with opiate-dependent animals receiving naltrexone, but no pretreatment with clonidine $(* p<0.05)$.

(Guzowski et al, 2000), may also be induced in the CeA by opiate withdrawal. However, we found a clear dissociation between Arc and Narp in this paradigm, suggesting that distinct combinations of IEGs may be recruited to produce different forms of synaptic modifications depending on the stimulus and cell type involved. As recent studies suggest that Arc is targeted to dendrites (Lyford et al, 1995), while Narp is targeted to axons (Reti et al, 2002a), this dissociation may indicate that opiate withdrawal induces plasticity in the synaptic connections between the Narppositive CeA neurons and their targets. Accordingly, future studies aimed at identifying the subset of CeA neurons that express Narp and their projections may be particularly useful in assessing the functional consequences of Narp induction in this paradigm.

Recent studies suggest that Narp has an agrin-like effect on a subset of central synapses expressing AMPA receptors (Fong and Craig, 1999). Overexpression of Narp in primary neuronal cultures increases the number of synapses expressing AMPA receptors; conversely, expression of dominant negative Narp constructs decreases this parameter (O'Brien et al, 1999, 2002). Based on these in vitro findings in developing neurons, it is conceivable that Narp exerts a similar effect in the adult nervous system, that is, it may mediate formation or enlargement of AMPA receptor clusters at synaptic contacts. In this context, it is noteworthy that increases in AMPA receptor binding have been observed in selected brain regions at $7 \mathrm{~h}$ after natural opiate withdrawal (Jang et al, 2000). However, that study did not examine limbic areas linked to aversive responses.

While Narp has been implicated in AMPA receptor clustering, it is important to emphasize that it may have other effects on neurons. For example, Narp has been shown to stimulate dendritic outgrowth in cortical neurons (Tsui et al, 1996). Thus, additional studies on Narp's functional role in neurons are needed to help elucidate its role in plasticity in the adult nervous system.

In summary, we have found that Narp is strongly induced in the extended amygdala by opiate withdrawal. As the 
amygdala plays a central role in mediating aversive responses, this finding suggests that Narp mediates experience-dependent changes in these responses. Accordingly, further studies are needed to define the range of stimuli that induce Narp in these key areas, which neuronal populations express Narp, and its role in the acquisition and retention of aversive memories.

\section{MATERIALS AND METHODS}

\section{Animals}

Experiments were performed on male Sprague-Dawley rats (Harlan), weighing 200-300 g. Animals were housed four per cage on a 12-h light-dark cycle. Food and water were available ad libitum and animals were treated in accordance with the guidelines of the Johns Hopkins University Animal Care and Use Committee. The numbers of animals used in each experimental paradigm are indicated in Table 1.

\section{Drugs}

Naltrexone (Sigma), naloxone (Tocris), $75 \mathrm{mg}$ morphine base implant pellets (NIDA), placebo pellets (NIDA), and clonidine (Sigma) were used. Naltrexone, naloxone, and clonidine were dissolved in normal saline.

\section{Drug Treatments}

Opiate dependence was induced in rats by the subcutaneous pellet implantation method. While under halothane anesthesia, animals were implanted with either two morphine pellets $(75 \mathrm{mg})$ or two placebo pellets. Opiate withdrawal was induced $72 \mathrm{~h}$ later by subcutaneous injection of an opiate receptor antagonist, either naltrexone $(1-1000 \mu \mathrm{g} / \mathrm{kg})$ or naloxone $(10-1000 \mu \mathrm{g} / \mathrm{kg})$. We conducted preliminary studies aimed at assessing the time course of Narp induction in opiate withdrawal induced by naltrexone $100 \mu \mathrm{g} / \mathrm{kg}$, and found that expression peaked at $4-6 \mathrm{~h}$ and returned to basal levels by $48 \mathrm{~h}$. Accordingly, we assayed Narp induction in this paradigm at $4 \mathrm{~h}$ after injection of the opiate antagonist. The treatment groups used for this study are presented in Table 1. Somatic signs of opiate withdrawal including body shakes, jumping, digging, tremor, ptosis, diarrhea, and chattering were observed in all animals receiving naltrexone or naloxone $100 \mu \mathrm{g} / \mathrm{kg}$ or above. In animals receiving naltrexone $10 \mu \mathrm{g} / \mathrm{kg}$, body shakes, ptosis, tremor, and diarrhea were observed, but less frequently. In animals receiving naltrexone $1 \mu \mathrm{g} / \mathrm{kg}$ or naloxone $10 \mu \mathrm{g} / \mathrm{kg}$, somatic signs of withdrawal were not observed. Controls for these studies were: (1) animals made opiate dependent, but treated with saline injection, rather than an opiate antagonist, at $72 \mathrm{~h}$ after morphine pellet implantation and (2) animals implanted with placebo pellets that received the opiate antagonist $72 \mathrm{~h}$ later.

To check if Narp was also induced in the extended amygdala during 'natural withdrawal' (or nonopiate antagonist precipitated), morphine pellets were removed from rats under halothane anesthesia 3 days after their implantation. Animals were then observed every $1-2 \mathrm{~h}$ and were killed $8 \mathrm{~h}$ after removal of the pellets. Control rats underwent sham surgery, including halothane anesthesia and clip replacement, but their morphine pellets were not removed. They were also killed $8 \mathrm{~h}$ later.

To check if blockade of opiate withdrawal also reduced induction of Narp in the extended amygdala, some animals were injected with clonidine $50 \mu \mathrm{g} / \mathrm{kg}$, i.p., $20 \mathrm{~min}$ before injection of naltrexone $100 \mu \mathrm{g} / \mathrm{kg}$.

As a control for Arc immunostaining in the amygdala, one animal also received electroconvulsive shock (as described in Reti and Baraban, 2000) and was killed $4 \mathrm{~h}$ later for processing of hippocampal sections.

\section{Antibodies}

In these studies, we used a rabbit polyclonal Narp antibody $(1: 3000)$ raised against a full-length (minus the signal sequence) GST-Narp fusion protein, as previously described (O’Brien et al, 1999). In previous studies, we have demonstrated that this antibody is highly specific for Narp, as assessed by immunobloting of brain extracts and immunohistochemistry (Reti and Baraban, 2000; Reti et al, $2002 a, b, c)$. Other primary antibodies used for immunohistochemistry were: rabbit polyclonal Arc (1:500; Lyford et al, 1995) and goat polyclonal c-Fos (1:100; Santa Cruz). The secondary antibodies were biotinylated polyclonal antirabbit (1:200; Vector) and anti-goat (1:200; Vector).

Table I Treatment Groups

\begin{tabular}{|c|c|c|c|c|}
\hline Group & Pellet & Treatment $(\mu \mathrm{g} / \mathrm{kg}) ;$ killed $4 \mathrm{~h}$ later unless stated otherwise & Rats/group & Immunoreactivity \\
\hline I & $\mathrm{m}$ & Naltrexone 1000 & 3 & Narp \\
\hline 2 & $\mathrm{~m}$ & Naltrexone 100; animals for c-fos immunoreactivity killed I h later & $5+2$ (c-fos) & Narp, c-fos, Arc \\
\hline 3 & $\mathrm{~m}$ & Naltrexone 10 & 5 & Narp \\
\hline 4 & $\mathrm{~m}$ & Naltrexone I & 4 & Narp \\
\hline 5 & $\mathrm{~m}$ & Normal saline & 5 & Narp, Arc \\
\hline 6 & $p$ & Naltrexone 100 & 4 & Narp, Arc \\
\hline 7 & $\mathrm{~m}$ & Naloxone 1000 & 3 & Narp \\
\hline 8 & $\mathrm{~m}$ & Naloxone 100 & 3 & Narp \\
\hline 9 & $\mathrm{~m}$ & Naloxone 10 & 3 & Narp \\
\hline 10 & $p$ & Naloxone 1000 & 3 & Narp \\
\hline | | & $\mathrm{m}$ & Pellet removal; killed $8 \mathrm{~h}$ later & 4 & Narp \\
\hline 12 & $\mathrm{~m}$ & Sham surgery; killed $8 \mathrm{~h}$ later & 4 & Narp \\
\hline 13 & $\mathrm{~m}$ & Clonidine pretreatment followed by naltrexone 100 & 4 & Narp \\
\hline
\end{tabular}

$\mathrm{m}=$ morphine pellets; $\mathrm{p}=$ placebo pellets. 


\section{Immunohistochemistry}

All animals were killed between approximately 17.00 and $19.00 \mathrm{~h}$. Animals were anesthetized with chloral hydrate (Sigma) $400 \mathrm{mg} / \mathrm{kg}$ i.p., then perfused transcardially with $150 \mathrm{ml} \mathrm{PBS}$, followed by $4 \%$ freshly depolymerized paraformaldehyde in PBS. Brains were removed and postfixed overnight for $14-16 \mathrm{~h}$ in $4 \%$ paraformaldehyde in PBS, before being transferred to $25 \%$ sucrose in PBS for cryoprotection. Sections $(20 \mu \mathrm{m})$ were cut on a sliding microtome and washed for $30-60 \mathrm{~min}$ in PBS before mounting on glass slides (Precleaned Superfrost Plus MicroSlides, VWR). After drying for approximately $1 \mathrm{~h}$, the mounted sections were rehydrated in PBS, and then boiled for $20 \mathrm{~min}$ in an antigen retrieval buffer (Tissue Retrieval Solution, Cell Marque). This step is essential for adequate visualization of Narp protein in paraformaldehyde-fixed brains. After cooling, the slides were washed in PBS and then placed in 3\% hydrogen peroxide in $20 \%$ methanol (in PBS) for $4 \mathrm{~min}$ to quench endogenous peroxidase in blood cells. Thereafter, they were washed twice more in PBS, 10 min each. Slides were then incubated in $1 \%$ Triton X-100 in PBS for 15 min and then washed further before blocking in 3\% bovine serum albumin (BSA) (Sigma) with $0.2 \%$ Triton X-100 in PBS. Sections were incubated in Narp antibody for a minimum of $20 \mathrm{~h}$ in $1 \%$ BSA in PBS. After three washes, 15 min each in PBS, sections were incubated in biotinylated-conjugated secondary antibodies in $1 \%$ BSA in PBS for a minimum of $16 \mathrm{~h}$. After further washing, sections incubated in biotinylated antibody were then incubated in an avidin-biotin solution and staining was visualized with $\mathrm{DAB}$ according to the manufacturer's instructions (VectaStain Elite kit, Vector). Following dehydration, these sections were coverslipped in Permount (Fischer Scientific).

Immunohistochemistry with c-Fos and Arc antibodies was conducted in a similar way except that sections were not boiled in antigen retrieval buffer nor immersed in Triton $1 \%$ for $15 \mathrm{~min}$.

For each rat used to monitor changes in the number of Narp-immunopositive cells, these cells were counted in four to six sections (counting either one or both sides independently) containing the structure being analyzed and the values obtained averaged. Sections counted for the $\mathrm{CeA}$ were cut midlevel through the nucleus at which the stria terminalis is positioned dorsomedially to the CeA (Figure 1c). Fields counted for the BNST were cut at a level corresponding to Figure 15 of Paxinos and Watson (1986) at the branching of the anterior commissure and fields counted for the shell of the NAc were cut at a level corresponding to Figure 12 of the same atlas at the anterior corpus callosum. To analyze the effects of multiple doses of opiate antagonists in the CeA, Narp-positive cell counts were compared using a one-way analysis of variance (ANOVA) for naloxone and naltrexone. When main effects were observed, post hoc comparisons were made using the Student's $t$-test with Bonferroni correction.

Narp terminal staining in the CeA was quantified using a reticule with a $5 \times 5,50 \mu \mathrm{m}$ grid. Squares that contained at least one Narp-positive fiber or bouton were counted as positive.

\section{ACKNOWLEDGEMENTS}

We thank Desheng Xu and Paul Worley for providing Narp and Arc antibodies, and Roy Wise, Martin Cassell and Thackery Gray for helpful discussions. This research was supported by NIH Grants DA14063 (IMR), DA00266 (JMB), DA00358 (JMB) and by a Johns Hopkins University Clinician Scientist Award (IMR).

\section{REFERENCES}

Berke JD, Paletzki RF, Aronson GJ, Hyman SE, Gerfen CR (1998). A complex program of striatal gene expression induced by dopaminergic stimulation. J Neurosci 18: 5301-5310.

Berkowitz BA, Ngai SH, Hempstead J, Spector S (1975). Disposition of naloxone: use of a new radioimmunoassay. J Pharmacol Exp Ther 195: 499-504.

Blasig J, Hollt V, Herz A, Paschelke G (1976). Comparison of withdrawal precipitating properties of various morphine antagonists and partial agonists in relation to their stereospecific binding to brain homogenates. Psychopharmacologia 46: 41-51.

Cassell MD, Gray TS, Kiss JZ (1986). Neuronal architecture in the rat central nucleus of the amygdala: a cytological, hodological, and immunocytochemical study. J Comp Neurol 246: 478-499.

Delfs JM, Zhu Y, Druhan JP, Aston-Jones G (2000). Noradrenaline in the ventral forebrain is critical for opiate withdrawal-induced aversion. Nature 403: 430-434.

Cassell MD, Freedman LJ, Shi C (1999). The intrinsic organization of the central extended amygdala. Ann NY Acad Sci 877: 217241.

Fong DK, Craig AM (1999). The Narp hypothesis? Neuron 23: 195 197.

Gawin FH, Kleber HD (1986). Abstinence symptomatology and psychiatric diagnosis in cocaine abusers. Clinical observations. Arch Gen Psychiatry 43: 107-113.

Gracy KN, Dankiewicz LA, Koob GF (2001). Opiate withdrawalinduced Fos immunoreactivity in the rat extended amygdala parallels the development of conditioned place aversion. Neuropsychopharmacology 24: 152-160.

Guzowski JF, Lyford GL, Stevenson GD, Houston FP, McGaugh JL, Worley PF et al (2000). Inhibition of activity-dependent arc protein expression in the rat hippocampus impairs the maintenance of long-term potentiation and the consolidation of longterm memory. J Neurosci 20: 3993-4001.

Guzowski JF, McGaugh JL (1997). Antisense oligodeoxynucleotidemediated disruption of hippocampal cAMP response element binding protein levels impairs consolidation of memory for water maze training. Proc Natl Acad Sci USA 94: 2693-2698.

Hope BT, Nye HE, Kelz MB, Self DW, Iadarola MJ, Nakabeppu Y et al (1994). Induction of a long-lasting AP-1 complex composed of altered Fos-like proteins in brain by chronic cocaine and other chronic treatments. Neuron 13: 1235-1244.

Hyman SE, Malenka RC (2001). Addiction and the brain: the neurobiology of compulsion and its persistence. Nat Rev Neurosci 2: 695-703.

Jang CG, Rockhold RW, Ho IK (2000). An autoradiographic study of $\left[{ }^{3} \mathrm{H}\right] \mathrm{AMPA}$ receptor binding and in situ hybridization of AMPA sensitive glutamate receptor A (GluR-A) subunits following morphine withdrawal in the rat brain. Brain Res Bull 52: $217-221$.

Jones MW, Errington ML, French PJ, Fine A, Bliss TV, Garel S et al (2001). A requirement for the immediate early gene Zif268 in the expression of late LTP and long-term memories. Nat Neurosci 4: 289-296.

Kelz MB, Chen J, Carlezon Jr WA, Whisler K, Gilden L, Beckmann AM et al (1999). Expression of the transcription factor delta 
FosB in the brain control sensitivity to cocaine. Nature 401: $272-276$

Koob GF (1999). The role of the striatopallidal and extended amygdala systems in drug addiction. Ann NY Acad Sci 877: 445-460.

Kosten TA (1994). Clonidine attenuates conditioned aversion produced by naloxone-precipitated opiate withdrawal. Eur J Pharmacol 254: 59-63.

Lyford G, Yamagata K, Kaufmann W, Barnes C, Sanders L, Copeland $\mathrm{N}$ et al (1995). Arc, a growth factor and activityregulated gene, encodes a novel cytoskeletal-associated protein that is enriched in neuronal dendrites. Neuron 14: 443-445.

Mucha RF (1987). Is the motivational effect of opiate withdrawal reflected by common somatic indices of precipitated withdrawal? A place conditioning study in the rat. Brain Res 418: 214-220.

Nader K, van der Kooy D (1996). Clonidine antagonizes the aversive effects of opiate withdrawal and the rewarding effects of morphine only in opiate withdrawn rats. Behav Neurosci 110: 389-400.

Nestler EJ (2001). Molecular basis of long-term plasticity underlying addiction. Nat Rev Neurosci 2: 119-128.

Nestler EJ, Barrot M, Self DW (2001). DeltaFosB: a sustained molecular switch for addiction. Proc Natl Acad Sci 98: 1104211046.

O'Brien RJ, Xu D, Mi R, Hopf C, Tang X, Worley P (2002). The role of the neuronal pentraxin Narp in the formation of excitatory synapse in cultured spinal neurons. J Neurosci 22: 4487-4498.

O’Brien RJ, Xu D, Petralia RS, Steward O, Huganir RL, Worley P (1999). Synaptic clustering of AMPA receptors by the extra- cellular immediate-early gene product Narp. Neuron 23: 309-323.

Paxinos G, Watson C (1986). The Rat Brain in Stereotaxic Coordinates, 2nd edn Academic Press: New York.

Pert CB, Pasternak G, Snyder SH (1973). Opiate agonists and antagonists discriminated by receptor binding in brain. Science 182: $1359-1361$.

Reti IM, Baraban JM (2000). Sustained increase in Narp protein expression following repeated electroconvulsive seizure. Neuropsychopharmacology 23: 439-443.

Reti IM, Minor LB, Baraban JM (2002). Prominent expression of Narp in central vestibular pathways: selective effect of labyrinth ablation. Eur J Neurosci 16: 1949-1958.

Reti IM, Reddy R, Worley PF, Baraban JM (2002a). Prominent Narp expression in projection pathways and terminal fields. $J$ Neurochem 82: 935-944.

Reti IM, Reddy R, Worley PF, Baraban JM (2002b). Selective expression of Narp, a secreted neuronal pentraxin, in orexin neurons. J Neurochem 82: 1561-1565.

Shaw-Lutchman TZ, Barrot M, Wallace T, Gilden L, Zachariou V, Impey $S$ et al (2002). Regional and cellular mapping of cAMP response element-mediated transcription during naltrexoneprecipitated morphine withdrawal. J Neurosci 22: 3663-3672.

Tsui CC, Copeland NG, Gilbert DJ, Jenkins NA, Barnes C, Worley PF (1996). Narp, a novel member of the pentraxin family, promotes neurite outgrowth and is dynamically regulated by neuronal activity. J Neurosci 16: 2463-2478.

Wall ME, Brine DR, Perez-Reyes M (1981). Metabolism and disposition of naltrexone in man after oral and intravenous administration. Drug Metab Dispos 9: 369-375. 